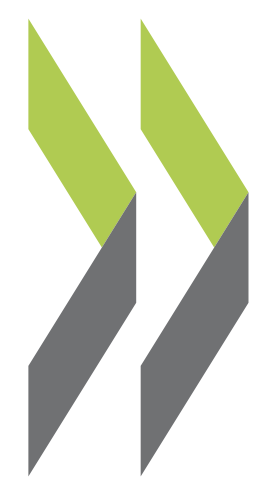

OECD Economics Department Working Papers No. 392

Enhancing Income

Convergence in Central

Europe after EU Accession
Patrick Lenain,

\section{kukasz Rawdanowicz}


Organisation de Coopération et de Développement Economiques

Organisation for Economic Co-operation and Development

16-Jun-2004

ECONOMICS DEPARTMENT

English - Or. English

ENHANCING INCOME CONVERGENCE IN CENTRAL EUROPE AFTER EU ACCESSION

ECONOMICS DEPARTMENT WORKING PAPERS No. 392

By Patrick Lenain and Lukasz Rawdanowicz

All Economics Department Working Papers are now available through OECD's Internet Web site at http://www.oecd.org 


\section{ABSTRACT/RÉSUMÉ \\ Enhancing income convergence in Central Europe after EU accession}

After nearly fifteen years of transition, the countries of Central Europe have entered the European Union on 1 May 2004. For the four countries that are members of the OECD (Czech Republic, Hungary, Poland and Slovak Republic), accession follows multiyear efforts of economic stabilisation and structural transformation, which have brought them large benefits. Although convergence towards higher levels of income appears to be a distant prospect at current trend growth rates, this is not a predetermined outcome. The experience of prior entrants suggests that much leeway is available within the framework of the European Union to undertake pro-growth policies. The most promising prospect in this respect appears to reside with employment creation, which has been so far lacking and led to a rather imbalanced pattern of growth. Bringing down labour taxes, easing employment protection legislation and reducing out-of-work benefits would make important contributions in this respect. While employment matters, strong productivity growth will continue to be an essential ingredient of the catching-up process.

JEL codes: F43, J21, J23, O11, O52, P31

Keywords: Central Europe, Czech Republic, Hungary, Poland, Slovak Republic, European Union, accession, economic growth, convergence, catching-up, transition, labour utilisation, productivity growth, diffusion of innovation

$* * * * * * *$

\section{Renforcer la convergence des revenus en Europe Centrale après les adhésions à l'Union européenne}

Le $1^{\text {er }}$ mai 2004, après presque quinze années de transition, les pays d'Europe centrale sont entrés dans l'Union européenne. Pour les quatre pays accédants qui sont Membres de l'OCDE (Hongrie, Pologne, République slovaque et République tchèque), l'adhésion couronne plusieurs années d'efforts de stabilisation économique et de transformation structurelle qui leur ont été très profitables. Même si la convergence vers des niveaux de revenu plus élevés semble une perspective lointaine aux taux de croissance actuels, l'issue n'est pas pour autant déterminée d'avance. L'expérience des précédents entrants donne à penser que le cadre de l'Union européenne offre une grande marge d'action pour engager des politiques favorables à la croissance. La voie la plus prometteuse à cet égard semble être la création d'emplois, qui a été jusqu'ici insuffisante et qui a engendré un profil de croissance assez déséquilibré. L'allégement de la fiscalité du travail, l'assouplissement de la législation sur la protection de l'emploi et la réduction des prestations d'inactivité seraient très utiles à cet égard. L'emploi est une source de croissance essentielle, mais une forte croissance de la productivité restera un ingrédient indispensable au processus de rattrapage.

Classification JEL: F43, J21, J23, O11, O52, P31

Mots-clés: Europe centrale, Hongrie, Pologne, République Tchèque, République Slovaque, Union européenne, accession, croissance économique, convergence, rattrapage, transition, utilisation du travail, croissance de la productivité, diffusion de l'innovation

\section{Copyright $\odot$ OECD 2004. All rights reserved.}

Applications for permission to reproduce or translate all, or part of, this material should be made to: Head of Publications Service, OECD, 2 rue André-Pascal, 75775 PARIS CEDEX 16, France. 


\section{TABLE OF CONTENTS}

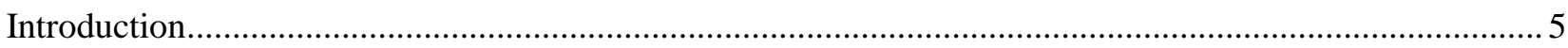

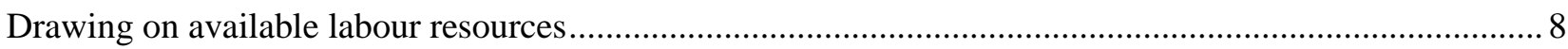

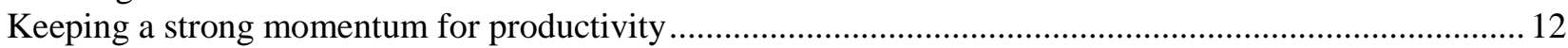

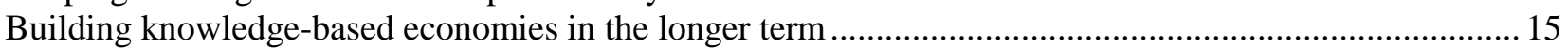

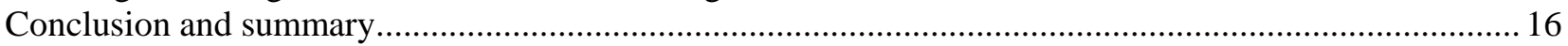

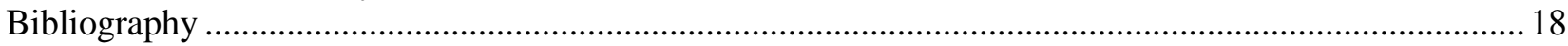

\section{Tables}

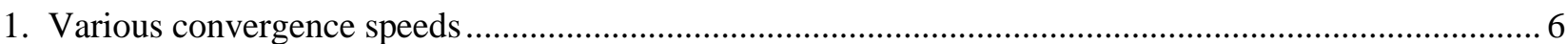

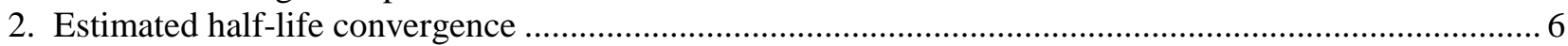

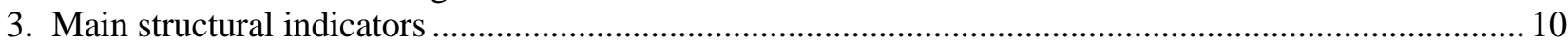

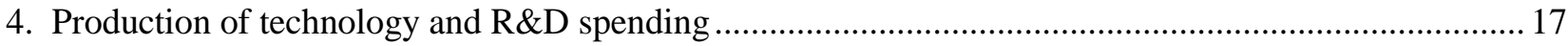

\section{Figures}

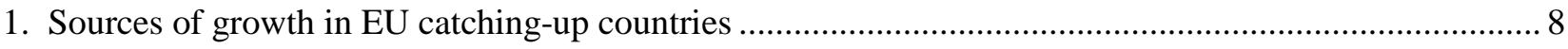

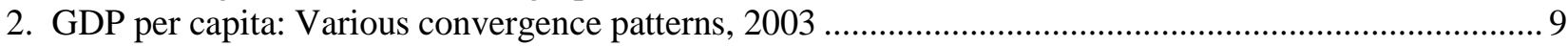

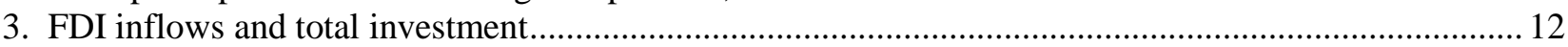

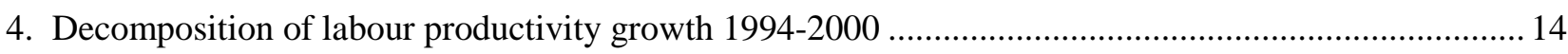


ECO/WKP(2004)15 
ECO/WKP(2004)15

\title{
ENHANCING INCOME CONVERGENCE IN CENTRAL EUROPE AFTER EU ACCESSION
}

\author{
Patrick Lenain and Lukasz Rawdanowicz ${ }^{1}$
}

\section{Introduction}

1. After nearly fifteen years of transition, the countries of Central Europe have entered the European Union on 1 May 2004. The present chapter examines the consequences of this event for the four acceding countries that are members of the OECD (Czech Republic, Hungary, Poland and Slovak Republic). ${ }^{2}$ For these countries, accession follows multiyear efforts of economic stabilisation and structural transformation, which have brought them large benefits, even though there are significant differences among them. ${ }^{3}$ Output has recovered from its sharp decline at the start of transition and now exceeds levels prevailing in 1989. Real GDP per capita has expanded over the past decade by 4 per cent annually on average in Poland, Hungary and the Slovak Republic, faster not only than in most advanced countries but also than in lessadvanced OECD members (Table 1). In the Czech Republic, where GDP per capita is substantially higher than in the other CEE4, growth has been less robust in the late 1990s, but picked up pace lately. It is hoped that membership in the European Union (EU) will not only lock in the progress achieved so far, but will also speed up the convergence of GDP per capita to western European levels.

2. The income gaps ${ }^{4}$ that would have to be bridged to fulfil these hopes are large in comparison to those of prior EU entrants. The four countries have income gaps vis-à-vis the OECD ranging from 39 per cent (Czech Republic) to 55 per cent (Poland) in terms of purchasing power parity. At the speed of convergence recorded since the mid-1990s, it would take between 30 and 40 years to bridge half of the income gap, making full convergence a distant prospect under current circumstances (Table 2). Achieving speedier catch-up should not be beyond reach, however, provided that more effective policies are put into place. Past experience suggests indeed that despite their strong lead in income levels and a supposedly lower scope for rapid income gains, successful emerging economies such as Ireland, Korea or Spain have

1. The authors were, at the time of drafting, respectively Counsellor and Consultant to the Economics Department of the OECD. The paper benefited from helpful discussions with officials of various government agencies as well as various academic institutions. The authors are also grateful for helpful comments and suggestions made by Jean-Philippe Cotis and other OECD colleagues. Special thanks also go to Debra Bloch for her skilled research assistance and Nathalie Macle for technical preparation of the document. The views expressed here are those of the authors and do not necessarily represent those of the OECD.

2. The four countries are hereafter referred to as "CEE4". This paper does not examine the prospects for the six other acceding countries, which are not members of the OECD. In this paper, European Union refers to pre-enlargement group of fifteen countries.

3. Recent developments in acceding countries are surveyed for instance in CEPR (2002), De Broeck and Koen (2000), EBRD (2003), European Commission (2001), Fidrmuc et al. (2002), Handler (2003), Martín et al. (2001) and in OECD Economic Surveys.

4. Differences in GDP per capita are hereafter simply referred to as "income gap". 
enjoyed comparatively high growth of GDP per capita relative to the CEE4 (Table 1). It would be unfair, however, to consider the recent decade as illustrative of the CEE4's growth potential. The growth of activity, which may have been depressed during the recent past by the tight monetary policies undertaken to achieve significant disinflation, could benefit in the future from a more favourable macroeconomic environment. As well, EU membership will help to spur growth thanks, inter alia, to the financial transfers from the structural funds, the removal of trade barriers in sensitive products and, possibly, participation in the euro area in due time.

3. While in the near term growth in the CEE4 is likely to accelerate beyond potential, in line with the European recovery, sustainably higher GDP increases will require further substantial progress in the area of structural reform. Indeed, past research (OECD, 2003a) clearly shows that the speed of convergence is highly responsive to structural and macroeconomic policies. Based on this research, this paper examines how convergence could be accelerated in the CEE4. The three findings of the paper are the following:

- Income convergence could be enhanced by adopting more job-friendly policies. The experience of prior entrants to the EU shows that successful catching-up involves both productivity and employment growth. In the CEE4, however, growth has until now been exclusively driven by labour productivity, with little or no contribution from labour utilisation. Employment rates have continuously declined and now are among the lowest in the OECD (except in the Czech Republic) while unemployment is at a record level in Poland and the Slovak Republic. While this may entail some degree of slack in the labour market, present levels of underemployment suggest that strong employment disincentives prevail in the tax and benefit systems. The countries could take advantage of a post-accession growth impetus to make labour market policies more job-friendly.

- Fast productivity growth will continue to matter for income convergence. While productivity has recently strongly increased, this may not last forever. A source of concern in this respect is the slow pace of capital accumulation, especially in Poland and Hungary, because investment is part of a scenario of convergence through increased productivity. Enhancing investment involves improving "framework" conditions, for which spurring product market competition is crucial. Progress has been made to foster competition in the run-up to accession, but the available evidence suggests that the business environment is not always transparent and that there is a need to level the playing field, especially in Poland. As well, public infrastructure in greater quantity and quality, especially for transportation networks, could well remove bottlenecks and stimulate productivity growth. Such reforms could also underpin a revival of foreign direct investment, which initially boosted business capital formation in these countries, but has tapered off recently.

- Over the longer term, the development of a knowledge economy will matter. Like other converging economies, the CEE4 have benefited from foreign technologies brought by exposure to trade and foreign direct investment. These technologies will however not always automatically spill over to domestic producers. International experience suggests that investment in human capital is particularly important to facilitate the transfer of foreign technologies. Higher research and development (R\&D) spending also has a role to play, although policies to achieve this are not straightforward. This involves not only improving tertiary education but also aiming at achieving better results in lower levels of education. 


\section{Drawing on available labour resources}

4. Over the past decade, growth in the CEE4 has almost exclusively been driven by productivity, while employment trends have generally been negative (Figure 1). This rather imbalanced pattern of growth has hindered the convergence towards higher income levels. The experience of prior entrants to the EU, notably Ireland and Spain, provides ample confirmation of the importance of job creation to economic convergence. As shown in Figure 2, Ireland went from a situation of below-average income level in 1986 to above-average income level in 2003 thanks to combined increases in productivity and employment. Spain has also moved closer to the average income level, although less rapidly than Ireland, with a pattern that has relied heavily on rising labour utilisation.

Figure 1. Sources of growth in EU catching-up countries 1995-2003

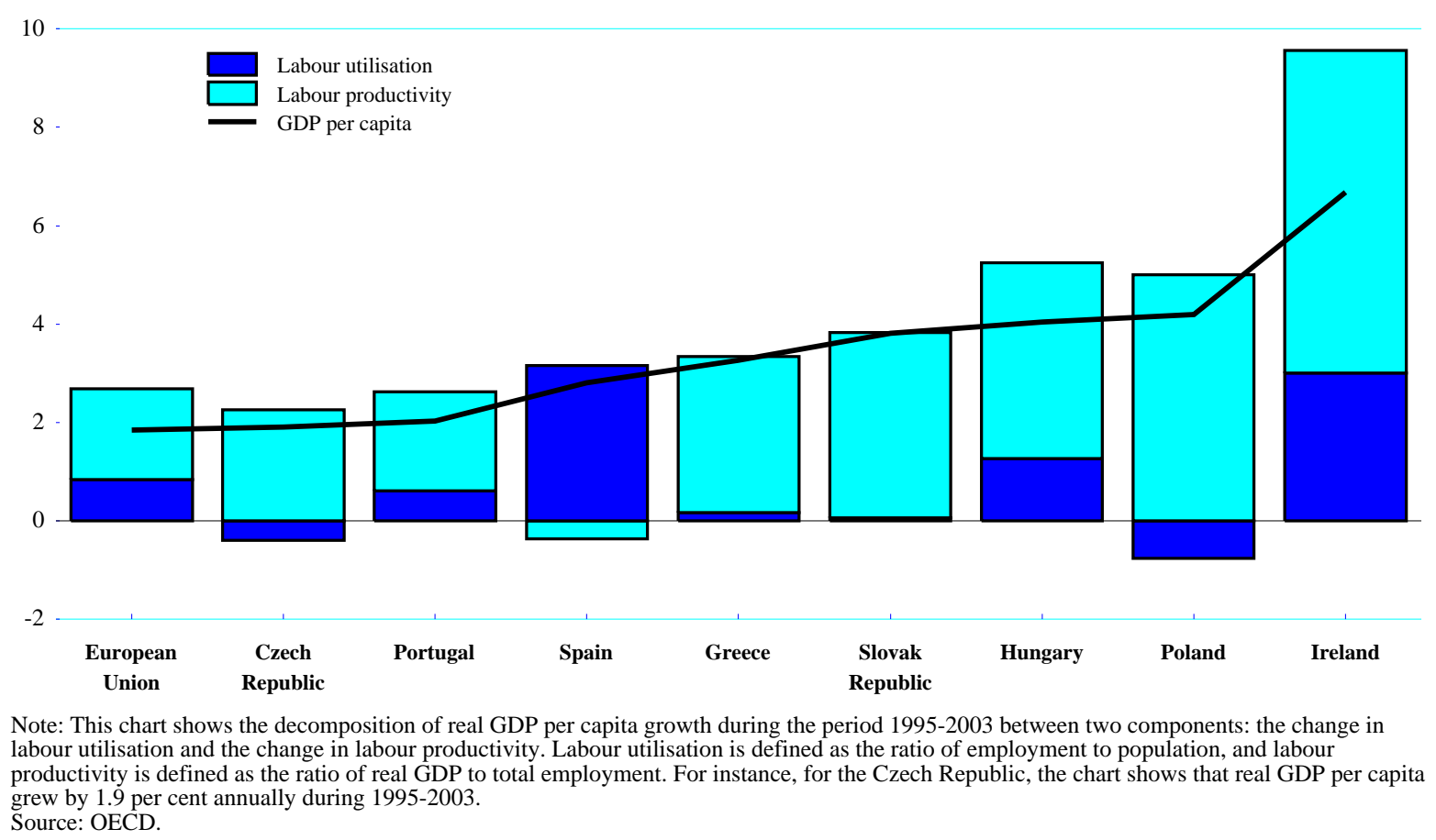


Figure 2. GDP per capita: Various convergence patterns, 2003 Index, EU15=100

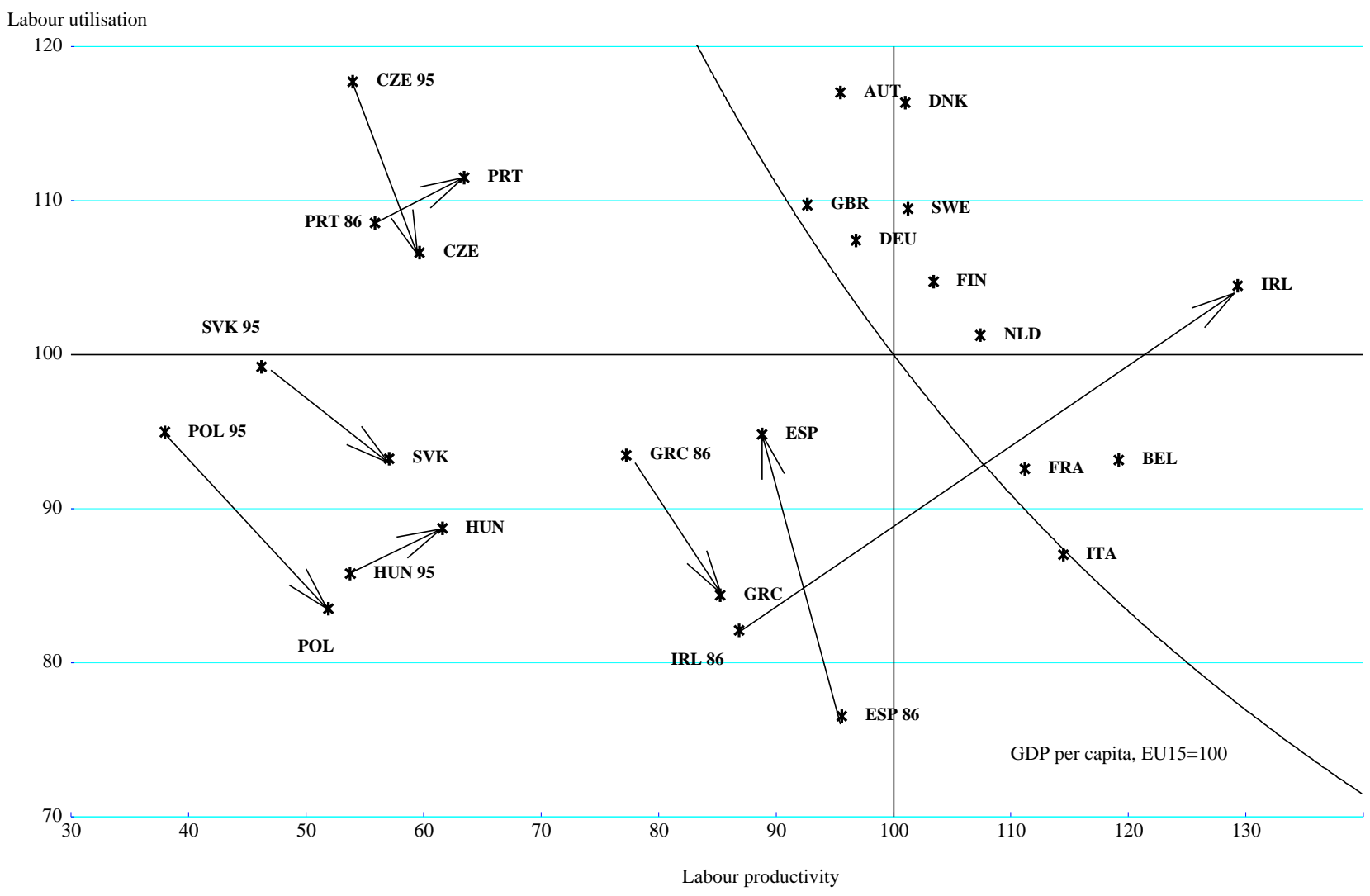

Note: This chart shows the decomposition of GDP per capita between its two components, which are labour utilisation (ratio of employment to population) and labour productivity (ratio of real GDP to employment). For instance, countries in the left upper corner of the chart combine a high degree of labour utilisation with a low level of productivity, while countries in the right lower corner combine a low degree of labour utilisation and a high level of productivity. All contributions are expressed in relation to the EU15. The curved line depicts the combination of labour utilisation and productivity that produce the average GDP per capita of the EU15 [(GDP/EMP) * (EMP/POP) = 100] Countries to the right of the curve have a higher income per capita than the EU average, while countries to the left of the curve have a lower one. The chart also shows the change of positions between 1986 and 2003 (for Ireland, Greece,Portugal and Spain) and between 1995 and 2003 (four acceding countries). Source: OECD.

5. Although differences prevail across countries, labour market trends have generally been adverse in the CEE4. Employment rates in Poland, Hungary and the Slovak Republic stand between 51 and 58 per cent of the working age population, among the lowest in the OECD (Table 3). In Hungary, those without a job have withdrawn from the labour market, resulting in low participation rates, even though a moderate improvement has been emerging in recent years. ${ }^{5}$ In Poland and the Slovak Republic, underemployment has been associated with OECD record unemployment rates of 17-20 per cent. Except for the Czech Republic, where employment levels have so far remained high, the proportion of the labour force either unemployed or inactive is thus rather high, in particular for the youth and older workers.

5. A large transfer of labour resources to the unofficial economy is also reported, which would have the effect of depressing the participation rate reported in official statistics, although the magnitude of this shift is difficult to measure precisely (OECD, 2003b). 


\begin{tabular}{|c|c|c|c|c|c|c|}
\hline \multirow{2}{*}{+2} & \multicolumn{3}{|c|}{$\begin{array}{l}\text { Table } 3 . \text { Main structural indicators } \\
\text { In per cent, unless otherwise indicated }\end{array}$} & & & \\
\hline & $\begin{array}{c}\text { Czech } \\
\text { Republic }\end{array}$ & Hungary & Poland & $\begin{array}{c}\text { Slovak } \\
\text { Republic }\end{array}$ & $\begin{array}{l}\text { Highest } \\
\text { OECD }\end{array}$ & $\begin{array}{l}\text { Lowest } \\
\text { OECD }\end{array}$ \\
\hline Employment rate $^{a}$ & 65.4 & 55.6 & 50.5 & 57.6 & 84.1 & 46.3 \\
\hline Unemployment rate $^{b}$ & 7.8 & 5.9 & 19.6 & 17.4 & 19.6 & 3.3 \\
\hline \multicolumn{7}{|l|}{ Labour income taxes } \\
\hline Tax wedge, single worker ${ }^{d}$ & 43.8 & 45.7 & 42.9 & 41.4 & 54.5 & 14.1 \\
\hline Tax wedge, married worker ${ }^{e}$ & 30.5 & 41.3 & 32.3 & 30.6 & 42.1 & 7.4 \\
\hline Composite index of total infrastructure ${ }^{f}$ & 67.0 & 66.1 & 54.1 & .. & 114.3 & 54.1 \\
\hline PISA Student performance indicator ${ }^{i}$ & 500.2 & 488.0 & 477.5 & .. & 543.1 & 410.3 \\
\hline Average years schooling ${ }^{j}$ & 10.2 & 10.9 & 11.5 & 11.0 & 13.0 & 7.2 \\
\hline \multicolumn{7}{|l|}{ Education Attainment ${ }^{k}$} \\
\hline primary, lower secondary & 20.1 & 32.6 & 25.9 & 20.8 & 22.6 & 73.7 \\
\hline upper secondary & 70.7 & 55.6 & 64.5 & 70.5 & 40.8 & 19.3 \\
\hline tertiary & 9.1 & 11.8 & 9.5 & 8.7 & 36.6 & 7.0 \\
\hline \multicolumn{7}{|c|}{$\begin{array}{l}\text { a) Data for } 2003 \text {, as a percentage of working age population (defined as 15-64). For Hungary, data refer to 2002. Both for the employment rate and the participation rate, the } \\
\text { highest OECD refers to Switzerland, lowest to Turkey. }\end{array}$} \\
\hline \multicolumn{7}{|c|}{$\begin{array}{l}\text { b) Data for 2003. Commonly used definitions (see the Economic Outlook Statistical Annex Table } 14 \text { for more information). Highest OECD refers to Poland, lowest to Mexico. } \\
\text { c) Data refer to 2002, annual working hours. Highest OECD refers to Poland, lowest to the Netherlands. }\end{array}$} \\
\hline \multicolumn{7}{|c|}{$\begin{array}{l}\text { d) Data for } 2003 \text {, based on } 100 \% \text { APW (average production worker earnings) without children, as } \% \text { of labour costs. Highest OECD refers to Belgium, lowest to Korea. } \\
\text { e) Data refer to } 2003 \text {, one earner at } 100 \% \text { APW with two children, as } \% \text { of labour costs. Highest OECD refers to Turkey, lowest to Ireland. }\end{array}$} \\
\hline k) Data for 2001. Education attainment rate for the tot & Highest OEC & ased on tertia & vel attainmen & rs to & o Turke & \\
\hline
\end{tabular}

6. These trends reflect factors influencing both labour demand and labour supply. At the early stage of transition, the combination of over-employment in state-owned enterprises and the concentration of some of them in uneconomic activities made a significant shakeout inevitable. Faced with large job losses, substantial social benefit and early-retirement systems were put in place to ease the cost to individuals directly affected by sectoral restructuring. These out-of-work benefits are partly to blame for the low level of employment. By providing laid off workers with very high and in many instances permanent unearned incomes, they dramatically reduced their incentives to take up new work - effectively denying their labour services to potential employers elsewhere in the economy.

7. In addition, the financing of out-of-work benefits has necessitated raising labour taxes to levels that depress employment creation, especially for the low-skilled, not unlike what has been observed in some EU countries. Labour costs are driven up in the four countries by taxes on labour income (personal income tax and social security contributions) representing between 40 and 45 per cent of labour costs -- among the highest in the OECD. In the central planning system, the tax system already relied on the taxation of labour income. At the start of transition, these already high labour taxes were further increased to finance welfare programmes introduced in an attempt to ease the social costs of transition (Feldmann, 2004). The shrinkage of employment caused a decline in the taxable base, making even higher tax rates necessary to maintain the financial viability of the welfare systems. 
8. Another factor that appears to have reduced the demand for low-skilled workers is the high level of statutory minimum wages, which currently stand at close to 40 per cent of average wages in the four countries. While this is not significantly different from levels prevailing in some EU countries, the minimum wage may have had a particularly detrimental impact in the CEE4, where low-skilled workers have been massively affected by the economic restructuring.

9. In addition, the strictness of dismissal protection laws has increased the cost of labour and made employers reluctant to hire new workers. The dismissal of workers typically involves negotiations with the trade unions, considerable advance notices and payments of sizeable severance benefits. Rules concerning collective dismissals are stricter than for individual dismissals and limits have been placed on the use of more flexible work forms such as fixed-term contracts. In the Czech Republic, for instance, apart from the notice period for collective dismissals being three months, the employer is obliged to notify and co-operate with trade unions and the labour office following a dismissal. If the court decides that the employer could have retained the employee, a salary must be paid after dismissal until a suitable job is found. While the strictness of employment protection legislation may not differ fundamentally from that prevailing in the $\mathrm{EU}$, there is a need to create job opportunities for large numbers of jobless persons. This calls for a particularly great degree of flexibility, especially in Poland and the Slovak Republic where unemployment is at record highs.

10. Another negative factor affecting the functioning of labour markets is low regional labour mobility, which has contributed to a very high inter-regional dispersion in unemployment rates in all the CEE4. Economic restructuring should in principle involve a migration of workers from highunemployment regions to more dynamic ones. Some highly industrialised regions have been particularly hit by the restructuring or liquidation of state enterprises during the transition and record above-average unemployment rates. In other regions, job creation has been dynamic thanks to, inter alia, foreign direct investments. The empirical evidence suggests, however, that the unemployed are unwilling or unable to change their place of residence and remain unemployed in their regions of origin. As a result, employers sometimes have difficulties hiring skilled workers in the more dynamic localities. This coexistence of high unemployment and hiring difficulties hinders the ability of economies to absorb shocks and to grow. This lack of mobility is caused by many factors, principle among which are the combination of the availability of significant social transfers and low-living costs in high-unemployment areas, and the rigidity of the housing market. Significant variation in living costs, combined with nationally defined transfer levels means that job-seekers are often better-off combining these revenues with non-market activities. Moreover, workers are often unable to change residence because neither rental accommodation nor vacant and affordable housing is available in fast-growing areas. While governments have spent large sums subsidising owner-occupied housing, little effort has been extended towards developing the rental market. Moreover, rent controls and excessive tenant protection have combined to limit private investment in the rental market. While some efforts have been made to liberalize these markets in all of these countries, these have thus far been limited in scope (CERGE-EI, 2003).

11. In sum, the factors explaining low employment in the CEE4 do not appear to be very different from those prevailing in several countries of the European Union, and the remedies are therefore similar. Making better use of the existing supply of labour would have positive effects on potential growth. If employment rates increased to the rather modest levels prevailing in the fifteen member states of the European Union, GDP per capita could increase by up to 7-10 percentage points in Hungary, Poland and the Slovak Republic. ${ }^{6}$ In order to raise employment levels, the four countries are starting to reform their labour markets to reduce the dismissal advance notice, increase the diversity and flexibility of labour contracts and to jointly lower social security contributions and out-of-work benefits. In the current context

6. This calculation is based on the assumption that raising employment rates does not lower productivity. If labour productivity were negatively affected, the impact on GDP per capita would be less significant. 
of high unemployment or low participation, labour market reforms may prove difficult to implement but could nonetheless be facilitated by the likely improvement of growth prospects that CEE4 may enjoy over the next few years.

\section{Keeping a strong momentum for productivity}

12. While productivity growth has been remarkably robust so far, it may have been boosted by temporary factors - such as the removal of low-skilled workers from the workforce - in addition to the underlying improvement of workers' individual efficiency. Establishing an environment propitious to sustained productivity growth will therefore remain essential to stimulate growth of GDP per capita. Two issues are sources of concern in this respect: the low level of capital accumulation in some countries and the insufficient degree of competition on product markets.

13. Countries that are converging towards higher levels of income typically accumulate capital at a faster rate than others. High rates of investment help to stimulate technical progress and are part of a scenario to raise labour productivity during the convergence process. Post-communist countries also face the additional challenge of modernising the stock of capital inherited from the past. In this respect, the current levels of investment in Poland and, to a lesser extent, in Hungary, are relatively low, in part reflecting the tapering-off of foreign direct investment (FDI) (Figure 3). FDI inflows strongly contributed to capital accumulation at the early stage of transition, but these inflows have recently weakened markedly, especially in Poland. It appears that foreign investors anticipated the enlargement and took market positions in these countries well before the formal date of accession. Investors have taken the opportunity of large-scale privatisation to gain market shares in certain sectors (such as banking or retail trade) and have established export manufacturing platforms ready to take advantage of the abolition of tariff and nontariff barriers.

Figure 3. FDI inflows and total investment Average 1998-2002

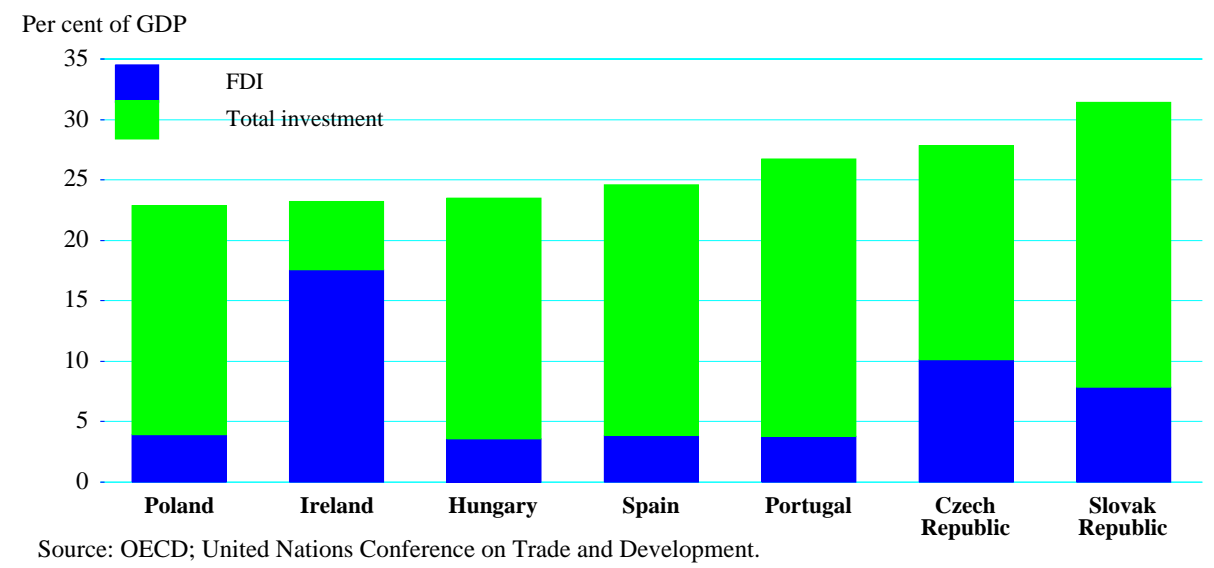


14. Attracting a second wave of foreign direct investment is within reach. After having attracted industrial manufacturers, CEE4 countries could very well host investment specialised in the provision of international services. ${ }^{7}$ Existing restrictions towards foreign investors may however be a hindrance to such inflows. The index of FDI restriction calculated by the OECD suggests that FDI restrictions were significant in Poland and the Slovak Republic in 1998-2000. The Czech Republic and Hungary appeared less restrictive, but without being as open to FDI as many EU member countries. ${ }^{8}$ Generally, while the manufacturing and tourism sectors were open to foreign investment, most of the administrative obstacles were found in the areas of network industries, notably electricity, telecommunications and transport. Given their large capital accumulation needs, these countries would benefit from being as open as possible. Accession to the European Union involves eliminating many of the restrictions that previously hindered foreign direct investment. However EU membership leaves considerable room for manoeuvre to national governments. The way in which this room is (or is not) used could have a significant impact on whether Central European economies become more or less attractive to foreign investors.

15. An important aspect of the accumulation of capital during the catching-up process is the upgrading of public transportation infrastructure. OECD research points to poor development of transportation infrastructure in some of the Central European countries, and especially in Poland. At present, both road and rail networks are seen as inadequate in most acceding countries. As business activities grow, transportation and communication infrastructure will become increasingly important. Insufficient infrastructural development could lead to bottlenecks and consequently to slower economic growth. Inadequate network infrastructure could be a particular deterrent to foreign investors, who might fear to be unable to import essential inputs and export finished products. Therefore, policies to promote investment in transportation infrastructure will be very important.

16. Another key driver of productivity growth is the degree of competition prevailing in product markets and, more specifically, the capacity of firms to operate without facing undue government interventions. The role played by product market competition in the process of catching-up has been emphasised by recent research at the OECD. This work shows for instance that removing barriers to competition can reduce the productivity gap versus the leader by as much as 10 percentage points in laggard industries (OECD, 2003a). Assessing the present degree of market competition in the four acceding economies is complex because their competition policies and regulatory frameworks are in a state of flux. As part of their transition, these economies have to a large extent dismantled previous commandand-control regulations, but significant government interventions still exist in some sectors. The OECD regulatory indicators computed for 1998 suggested that there was still a large scope for catching-up with best-practice countries in this area. Admittedly, regulatory reform has progressed since then. In particular, explicit barriers to international trade (notably import tariffs) have been lowered from their high levels and size of the public sector has been reduced.

7. The Czech Republic has for instance recently hosted investments in the sectors of accounting and international air shipments.

8. $\quad$ Golub (2003). 
17. Closing the overall productivity gaps involves not only increasing productivity within sectors or firms, but also reallocating jobs across sectors. Indeed, the long term process of economic development implies shifting labour resources towards activities producing higher value-added products and services. With this reallocation of labour, the structure of less-advanced economies becomes progressively more similar to that of developed economies. Recent empirical research suggests that productivity developments in the European Union vis-à-vis the United States has been positively influenced by this "shift effect" in the 1980s and 1990s (European Commission, 2003). The contribution of the shift effect, in principle, should be the largest at early stages of convergence. There are clear signs, however, that this reallocation of labour towards more productive activities has often been delayed in the CEE4 by various policies, such as prolonged subsidisation of declining industries (mining, heavy industries, etc.) and social security schemes allowing particular sectors -- for instance agriculture -- to benefit from exceptionally favourable treatment. Such barriers to exit have contributed to slow down productivity growth in various Central European countries. The most striking example is that of the Polish agricultural sector where farms still employ about one-fifth of the labour force but produce only 3 per cent of Poland's GDP. As shown by Figure 4, the contribution of the "shift effect" to productivity growth is smaller in Poland than in the other CEE4, although it could have been much more important in view of the larger size of the agricultural sector.

Figure 4. Decomposition of labour productivity growth 1994-2000

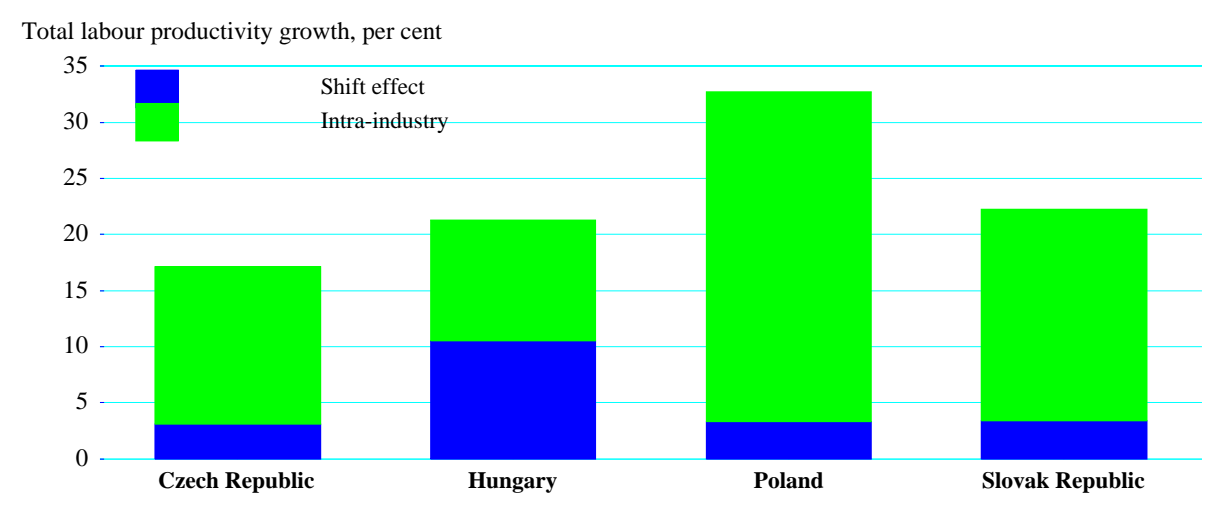

Note: The chart shows the decomposition of productivity growth between intra-industry effect and the shift effect across industries. The first element is calculated as the sum of industry productivity growth rates, weighted by the initial output shares. The second element is the sum of changes in input shares, weighted by the relative productive level. More specifically, the second element is calculated as:

$$
\sum_{i} \frac{L P_{i, t-1}}{L P_{t-1}} \cdot\left(\frac{L_{i, t}}{L_{t}}-\frac{L_{i, t-1}}{L_{t-1}}\right)
$$

with LP the level of productivity, $L$ the level of employment and $i$ the various sectors. In this chart, the economy is divided between six sectors using the International Standard of Industrial Classification nomenclature.

Source: OECD STAN database. 


\section{Building knowledge-based economies in the longer term}

18. The diffusion of technology is an important ingredient of the convergence process. ${ }^{9}$ Several interrelated channels are at work in catching-up economies to facilitate the absorption of technology. Exposure to international trade is one of such channel, because it creates technological linkages between suppliers and purchasers. Foreign direct investment also works in this direction, as technology is transferred from parent to subsidiary companies, and then from subsidiary companies to local suppliers (OECD, 2002). Integration into the European Union can help the transfer of technology through various channels such as skilled labour migration, R\&D or academic cooperation.

19. The diffusion of technology is, however, not an automatic process. The absorption of technology transfers depends to a large extent on the appropriateness of local conditions. These include the degree of product market competition (discussed above) but also importantly the qualification of the labour force and the availability of a research community capable of transposing foreign technologies.

20. A well educated and versatile labour force is an important prerequisite of harnessing the benefits of technology. Workers that have followed a well-constructed general curriculum, that teaches them how to learn -- rather than acquired specific skills -- are better prepared to adapt to changing requirements in the job market. Thus, investment in general education and other aspects of human capital is paramount to maximise the benefits from technology spillovers. The CEE4 have high degrees of educational achievement as measured by the average years of education or enrolment rates among recent cohorts. Average years of schooling range between ten and eleven years -- about the same as in the European Union and more than in Southern Europe. The education system traditionally put a lot of emphasis on primary and secondary education, and, as a result, between 65 and 70 per cent of the average population has attained an upper secondary level of education. ${ }^{10}$ Indeed, according to recent research from the Programme for International Student Assessment (PISA), the overall literacy performances are close to the average of Member countries and above what would be expected given the levels of GDP per capita or spending per student in the CEE4.

21. Nevertheless, the secondary education system in Central Europe still places too much emphasis on imparting specific skills through passive learning and memorising, which does not prepare young people well for market-based economies where adaptability, flexibility and autonomy are important (CERGE-EI, 2003). For instance, surveys of business employers in the Slovak Republic indicate that the public education system emphasised passive learning, which has resulted in poor managerial and language skills ${ }^{11}$ of the school leavers as well as their inability to cope with real-life situations in the workplace (OECD, 2004). While the share of general courses in most curricula has increased, the education system of the four countries traditionally emphasises vocational training, at the expense of general education. Workers who have completed vocational training have highly specialised skills but are ill-prepared for coping with the changing demands of a market economy (Feldmann, 2004). Various policies are underway to reform the education systems and adapt them to the challenges of modern times.

22. Investment in university education is particularly important to train skilled workers and harness the benefits of new technologies. A study based on a cross-section of individuals during the years of communism and transition suggests that the structure of wages has changed considerably since the

9. Acemoglu et al. (2002); Aghion and Cohen (2004).

10. Apart from Hungary, which has a lesser degree of attainment.

11. Training in foreign languages varies across countries, however. The Czech Republic has a high proportion of students fluent in English and German. 
emergence of a market economy in the Czech Republic (Münich, 2003). Individuals who have seen the largest remuneration increase are those with high school diplomas and university degrees. This higher rate of return to education stimulates enrolment in tertiary education in Central Europe, notably in Poland and Hungary, where the share of graduates with a tertiary education has risen fast (Feldmann, 2004). By contrast, demand for tertiary education far exceeds supply in the Czech Republic, where the availability of classroom seats is limited by financial constraints (CERGE-EI, 2003). The introduction of tuition fees in tertiary education, flanked by student loan arrangements, ${ }^{12}$ could be one possible option to ease these financial constraints. Accession to the European Union should also help to improve access of students to the universities of the existing Member states. The rationale for such arrangements is that this is an area in which private returns exceed social returns (Blöndal et al., 2002).

23. R\&D intensity is also an important factor of technology diffusion. Although catching-up economies are distant from the technology frontier, their research institutions can nevertheless play an important role in monitoring, absorbing and adapting new technology. Recognising this important role, it is worrisome that the levels of R\&D spending in the four acceding countries are among the lowest in the OECD (Table 4). Public research centres, such as scientific academies or branch laboratories, were deprived of resources at the start of the transition process and some research institutions have become commercial ventures. In the enterprise sector, research centres have often been sharply downsized after privatisation. Foreign investors have generally brought technologies from abroad rather than developing them locally. Thus, it will be important to find a new impetus to establish an environment propitious to the development of national R\&D capabilities.

\section{Conclusion and summary}

24. In sum, while convergence towards higher levels of income appears to be a distant prospect for the CEE4 under current circumstances, this is not a predetermined outcome. The experience of prior entrants suggests that much leeway is available within the framework of the European Union to undertake pro-growth policies. The most promising prospect in this respect appears to reside with employment creation, which has been so far lacking and led to a rather imbalanced pattern of growth. The causes of this employment underperformance are similar to those that have been observed in other OECD member countries, including in the European Union, and the remedies are therefore also similar. Bringing down labour taxes, easing employment protection legislation and reducing out-of-work benefits would make important contributions. While present circumstances in the budgetary sphere and the labour market situation may not be ideal for such reforms, a renewed growth impetus could provide the right opportunity. While employment matters, strong productivity growth will continue to be an essential ingredient of the catching-up process. Essential to this are reforms that underpin a stronger degree of competition, including greater transparency in competition rules. Boosting the pace of capital accumulation will depend significantly on FDI. Creating more auspicious conditions for a second wave of investment - more tilted towards services - could therefore be important, as well as upgrading transportation infrastructure. Over the longer term, building knowledge economies would become increasingly crucial to sustain a fast convergence. This points to the need of investment in knowledge capital, both in tertiary and lower levels of education, and in creating adequate conditions for R\&D activities.

12. Schemes involving tuition fees subject to income-conditional repayments have a proven track record in a number of OECD countries. 
Table 4. Production of technology and R\&D spending

\begin{tabular}{|c|c|c|c|c|}
\hline & $\begin{array}{c}\text { Share of ICT } \\
\text { manufacturing } \\
\text { in total } \\
\text { manufacturing } \\
\text { value-added, 2000 }\end{array}$ & $\begin{array}{c}\text { R\&D spending } \\
\text { in \% of GDP, } \\
2000\end{array}$ & $\begin{array}{c}\text { Business R\&D } \\
\text { in \% of GDP, } \\
2000\end{array}$ & $\begin{array}{c}\text { R\&D by } \\
\text { foreign } \\
\text { affiliates }^{a}\end{array}$ \\
\hline Poland & .. & 0.7 & 0.3 & 12.1 \\
\hline Spain & 3.2 & 0.9 & 0.5 & 31.0 \\
\hline Slovak Republic & 3.3 & 0.7 & 0.4 & 19.0 \\
\hline Czech Republic & 4.2 & 1.3 & 0.8 & 7.7 \\
\hline Portugal & 4.5 & 0.8 & 0.2 & 30.8 \\
\hline Germany & 5.0 & 2.5 & 1.8 & 19.0 \\
\hline Canada & 5.8 & 1.9 & 1.1 & 31.6 \\
\hline France & 6.3 & 2.2 & 1.4 & 16.4 \\
\hline Netherlands & 6.8 & 1.9 & 1.1 & 21.5 \\
\hline Hungary & 9.3 & 0.8 & 0.4 & 78.5 \\
\hline United Kingdom & 9.7 & 1.9 & 1.3 & 39.4 \\
\hline United States & 12.8 & 2.8 & 2.1 & 15.0 \\
\hline Ireland & 18.7 & 1.2 & 0.8 & 65.2 \\
\hline Finland & 21.7 & 3.4 & 2.4 & 14.2 \\
\hline
\end{tabular}

Note: National sources adjusted to OECD definitions; coverage may however differ across countries.

a) In per cent of business sector R\&D spending, various years.

Source: OECD. 


\section{BIBLIOGRAPHY}

ACEMOGLU, D., P. AGHION and F. ZILIBOTTI (2002),"Distance to frontier, selection and economic growth", NBER Working Paper, No. 9066, Cambridge, MA.

AGHION, P. et E. COHEN (2004), "Éducation et croissance", Rapport du Conseil d'Analyse économique, La Documentation Française, Paris.

BLÖNDAL, S. S. FIELD and N. GIROUARD (2002), "Investment in human capital through postcompulsory education and training: selected efficiency and equity aspects", OECD Economics Department Working Papers, No. 333, Paris.

CEPR (2002), "Who's Afraid of the Big Enlargement?", CEPR Policy Paper, No. 7, June, London.

CERGE-EI (2003), "Czech Republic 2002 - Invited to the EU”, Centre for Economic Research and Graduate Education of Charles University \& Economics Institute of the Academy of Sciences of the Czech Republic.

DE BROECK, M. and V. KOEN (2000), "The 'Soaring Eagle': Anatomy of the Polish Take- Off in the 1990s", International Monetary Fund, WP/00/6.

EBRD (2003), Transition Report 2003, European Bank for Reconstruction and Development, London.

EUROPEAN COMMISSION (2001), "Real convergence in candidate countries, past performance and scenarios in the pre-accession economic programmes", ECFIN/708/01-EN, Brussels.

EUROPEAN COMMISSION (2003), The EU Economy: 2003 Review, Brussels.

FELDMANN, H. (2004), "How flexible are labour markets in the EU accession countries Poland, Hungary and the Czech Republic?", Forthcoming in Comparative Economic Studies, Vol. 46, No. 2.

FIDRMUC, J., J. FIDRMUC and J. HORVATH (2002), "Visegrad Economies: Growth Experience and Prospects", Report prepared for the GDN global research project: determinants of economic growth, Centre for European Integration Studies, Bonn.

GOLUB, S. (2003), "Measures of restrictions on inward foreign direct investment for OECD countries", OECD Economics Department Working Papers, No. 357, Paris.

HANDLER, H. (ed.) (2003), Structural Reforms in the Candidate Countries and the European Union, Austrian Ministry for Economic Affairs and Labour, Economic Policy Center, Vienna.

MARTÍN, C., F.J. VELÁSQUEZ and F. FUNCK (2001), "European Integration and income convergence", World Bank, mimeo. 
MÜNICH, D. (2003), Human Capital in Transition - Czech Students and Workers Adapting to the Market, CERGE-EI, Prague.

OECD (2002), Foreign Direct Investment for Development - Maximising Benefits, Minimising Costs, OECD, Paris

OECD (2003a), The Sources of Economic Growth in OECD countries, OECD, Paris.

OECD (2003b), Economic Survey of Hungary, Paris.

OECD (2004), Economic Survey of the Slovak Republic, Paris. 


\section{WORKING PAPERS}

The full series of Economics Department Working Papers can be consulted at www.oecd.org/eco/Working_Papers/

391. Asset Price Cycles, “One-Off” Factors and Structural Budget Balances (June 2004) Nathalie Girouard and Robert Price

390. Channels for Narrowing the US Current Account Deficit and Implications for Other Economies (May 2004) Anne-Marie Brook, Franck Sédillot and Patrice Ollivaud

389. Product Market Competition and Economic Performance in Norway (May 2004) Jens Høj and Michael Wise.

388. Product Market Competition and Economic Performance in Sweden (May 2004) Deborah Roseveare, Martin Jørgensen and Lennart Goranson

387. Product Market Competition and Economic Performance in Japan (May 2004) Jens Høj and Michael Wise

386. Migration and Integration of Immigrants in Denmark (May 2004) Deborah Roseveare and Martin Jørgensen

385. Factors Driving Risk Premia (April 2004) Torsten Sløk and Mike Kennedy

384. Rationalising Public Expenditure in the Slovak Republic (March 2004) Rauf Gönenç and Peter Walkenhorst

383. Product Market Competition and Economic Performance in Switzerland (March 2004) Claude Giorno, Miguel Jimenez and Philippe Gugler

382. Differences in Resilience between the Euro-Area and US Economies (March 2004) Aaron Drew, Mike Kennedy and Torsten Sløk

381. Product Market Competition and Economic Performance in Hungary (March 2004) Carl Gjersem, Philip Hemmings and Andreas Reindl

380. Enhancing the Effectiveness of Public Spending: Experience in OECD Countries (February 2004) Isabelle Joumard, Per Mathis Kongsrud, Young-Sook Nam and Robert Price

379. Is there a Change in the Trade-Off between Output and Inflation at Low or Stable Inflation Rates? Some Evidence in the Case of Japan (February 2004) Annabelle Mourougane and Hideyuki Ibaragi

378. Policies bearing on product market competition and growth in Europe (January 2004) Carl Gjersem

377. Reforming the Public Expenditure System in Korea (December 2003) Young-Sook Nam and Randall Jones

376. Female Labour Force Participation: Past Trends and Main Determinants in OECD Countries (December 2003) Florence Jaumotte

375. Fiscal Relations Across Government Levels (December 2003) Isabelle Joumard and Per Mathis Kongsrud 
374. Health-Care Systems: Lessons from the Reform Experience (December 2003) Elizabeth Docteur and Howard Oxley

373. Non-Tariff Measures Affecting EU Exports: Evidence from a Complaints-Inventory (December 2003) Peter Walkenhorst and Barbara Fliess

372. The OECD Medium-Term Reference Scenario: Economic Outlook No. 74 (November 2003) Peter Downes, Aaron Drew and Patrice Ollivaud

371. Coping with Ageing: A Dynamic Approach to Quantify the Impact of Alternative Policy Options on Future Labour Supply in OECD Countries

(November 2003) Jean-Marc Burniaux, Romain Duval and Florence Jaumotte

370. The Retirement Effects of Old-Age Pension and Early Retirement Schemes in OECD Countries (November 2003) Romain Duval

369. Policies for an Ageing Society: Recent Measures and Areas for Further Reform (November 2003) Bernard Casey, Howard Oxley, Edward Whitehouse, Pablo Antolin, Romain Duval, Willi Leibfritz

368. Financial Market Integration in the Euro Area (October 2003) Carl Gjersem

367. Recent and Prospective Trends in Real Long-Term Interest Rates: Fiscal Policy and Other Drivers (September 2003) Anne-Marie Brook

366. Consolidating Germany's finances: Issues in public sector spending reform (September 2003) Eckhard Wurzel

365. Corporate Taxation of Foreign Direct Investment Income 1991-2001 (August 20030) Kwang-Yeol Yoo

364. Indicator Models of Real GDP Growth in Selected OECD Countries (July 2003) Franck Sédillot and Nigel Pain

363. Post-Crisis Change in Banking and Corporate Landscapes - the Case of Thailand (July 2003) Margit Molnar

362. Post-Crisis Changes in Banking and Corporate Landscapes in Dynamic Asia (June 2003) Margit Molnar

361. After The Telecommunications Bubble (June 2003) by Patrick Lenain and Sam Paltridge

360. Controlling Public Spending in Iceland (June 2003) Hannes Suppanz

359. Policies and International Integration: Influences on Trade and Foreign Direct Investment (June 2003) Giuseppe Nicoletti, Steve Golub, Dana Hajkova, Daniel Mirza, Kwang-Yeol Yoo

358. Enhancing the Effectiveness of Public Spending in Finland (June 2003) Philip Hemmings, David Turner and Seija Parviainen

357. Measures of Restrictions on Inward Foreign Direct Investment for OECD Countries (May 2003) Stephen S. Golub 